\title{
Social Justice Leadership and Navigating Systems of Inequity in Educational Spaces
}

\author{
Catherine Marshall, Ronda Taylor Bullock, and Meg Goodhand
}

\section{Contents}

The Case of Professors Moving from Disgruntled to Change-Making ................. 378

The Case of Disrupting Racism: White Teachers in White T's ..................... 379

The Case of Disrupting Heteronormativity at the Elementary Level .................. 380

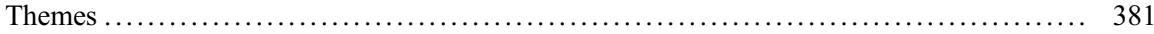

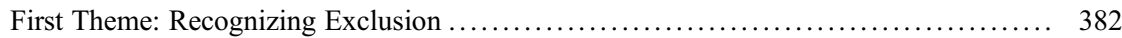

Second Theme: Recognizing Being Marginalized ........................... 383

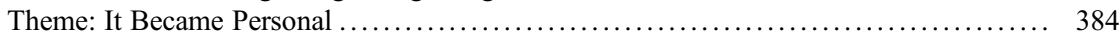

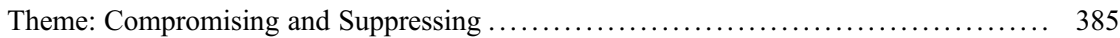

Theme: Sacrifices Had to Be Made for Managing Our Lives ....................... 386

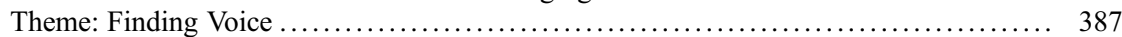

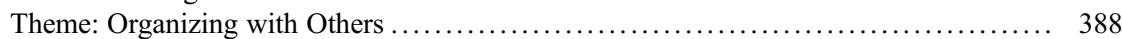

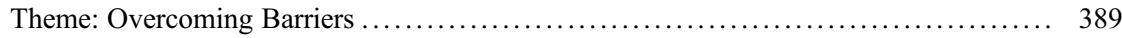

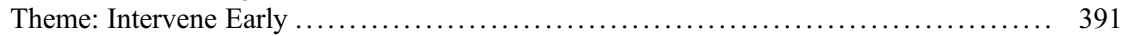

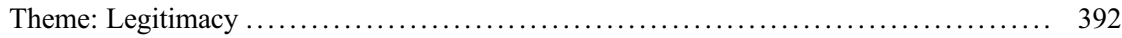

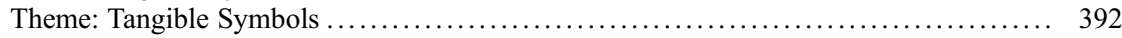

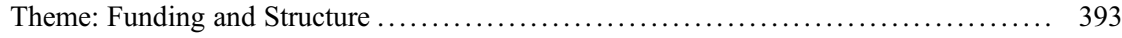

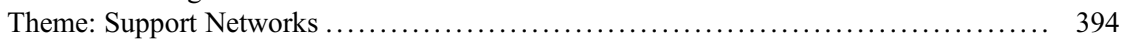

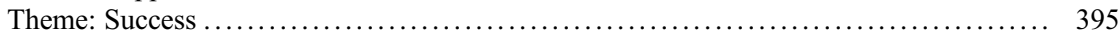

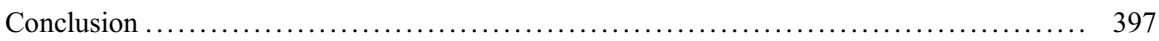

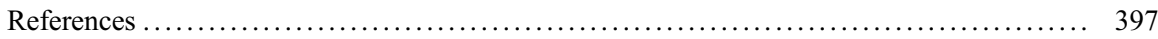

C. Marshall $(\bowtie) \cdot$ M. Goodhand

University of North Carolina, Chapel Hill, NC, USA

e-mail: marshall@email.unc.edu; meg.goodhand@gmail.com

R. Taylor Bullock

we are (Working to Extend Anti-racist Education), Durham, NC, USA

e-mail: ronda@weare-nc.org 


\section{Abstract}

Social justice leadership connects theory to action. Those who choose to challenge hegemonic practices, disrupting the status quo, are often met with resistance and hostility. The field of education is rife with its own systems of inequities that need to be disrupted (Spring, 2018). In this chapter, we elicit reflections from three social justice leaders as they think back on their journeys navigating policies and politics to create socially just educational spaces.

\section{Keywords}

Equity Social justice $\cdot$ Anti-racism $\cdot$ Heteronormativity $\cdot$ Counternarrative $\cdot$ Feminism · Heterosexism · Bigotry · Grassroots movement $\cdot$ Seed money · Critical scholars

In publications, comfortable offices, and boardrooms, people may expound upon ideals of equity and social justice. But something must happen to link knowledges and theories to actual interventions that support equitable practices. This chapter explores three such happenings.

For those ensconced in traditional stances about objectivity in research, to take an openly prosocial justice, even ideological stance (Lather, 1991), seems like a big leap. One wonders, how will this affect my stature as a scholar? Will I be seen as one of those people with a chip on her shoulder? Will my work now be labelled "overly subjective"? Will I be able to get any of this work published so that it helps my future promotions?

For those in the practitioner trenches in school systems, overt acts that challenge existing assumptions and practices are risky too. Will I be the lone, idealist pioneer, leading a movement that nobody joins? Will I still be seen as a credible, competent, educator, who can be trusted to manage a district, a school, a classroom, any group? Or will the label "troublemaker" hound me forever?

Traditional educator training and research have been inadequate for upsetting persistent patterns of inequities in schooling. Those who are different in languages, religions, abilities, and cultures of origin and those who are poor, gay, or female, are still floundering. It is an exhausting task, sorting through bureaucratese, token policies and programs in search of a voice, a discourse, an advocate, a coalition, or a politician that actually makes a difference. Trends in US policies, in fact, undermine equity and social justice efforts. Policy moves undermining affirmative action, linking welfare to work, taxpayer-subsidized vouchers for schools with programming that discriminates on the basis of religion and SES, or constraining teaching to restrained, aligned curricula - all ruin the possibilities that schooling will be the tool or lever for redressing persistent patterns of inequity. Further, educator training, while providing discrete courses for cultural diversity and making connections with community, still shy away from one critical question: what about the reality that schooling is ensconced in a political and economic system that was created with assumptions such as: white males should be the leaders, capitalist and competitive 
forces should be supported so there's a controlled and taxed labor force ready to work it, and people who are marginalized (e.g., gay, dark-skinned, Native American, differently abled, non-Christian, "foreign," chronically hungry, "unhealthy," and so on) are deficient - pitiable but undeserving of more than a free Thanksgiving meal?

What moves and supports anyone to challenge bureaucracy, to go beyond selfsatisfied comfortable statuses, to let go of hard-earned privileges and statuses to engage in the deep discomfort of really seeing the realities that critical scholars point out? The grad students, when exposed to Spring's (2018) and others' histories for schooling and US policy practices that sort and discriminate, are horrified for a few class hours, then go back to the eager pursuit of proving their competence in those bureaucracies. The scholar, eager to have her critical insights for research funded, and used, in circles where power and money are distributed, hedges and represses critical questions.

What does this mean, as people progress from realizing that inequities are being perpetuated toward actually finding ways to intervene, toward actually making a difference? (Fig. 1) Theoharis posited a useful model for envisioning a progression toward taking action for social justice: The model envisions the move from denying the existence of practices and policies that discriminate, to understanding, to actively intervening. This model guided the authors' questions and was useful for framing of progressions shown in the cases presented in this chapter.

As this Handbook demonstrates, there exist places and groups and literatures that lay the groundwork for substantive change. We identified three cases that are exemplars of social justice actions and used a modification of narrative and life history approach to present our analyses. We interviewed the leaders using a protocol aimed at understanding the elements common in the inspiration, passion, the strategies and resources, and the barriers and successes for each case.

As can be seen, the model depicts a progression of a potential social justice leader, from "I don't recognize social justice challenges," to "I know lots of leadership skills

\begin{tabular}{|c|c|}
\hline $\begin{array}{l}\text { A } \\
\text { Possess passion for justice } \\
\text { Can do the work }\end{array}$ & $\begin{array}{l}\text { B } \\
\text { Possess passion for justice } \\
\text { Can NOT do the work }\end{array}$ \\
\hline $\begin{array}{l}\text { C } \\
\text { Lack passion for justice } \\
\text { Can do the work }\end{array}$ & $\begin{array}{l}\mathrm{D} \\
\text { Lack passion for justice } \\
\text { Can NOT do the work }\end{array}$ \\
\hline
\end{tabular}

Fig. 1 Social justice leadership responses. (Adapted from Theoharis, 2004) 
but I don't care about using those skills for social justice interventions," to "I recognize and care but don't have particular social justice knowledge and skills," to, finally, "I have a passion for social justice, and I know how to find leadership skills and resources to intervene." We now present, examples of this progression, the backgrounds of the three cases, illustrated with interview data, the background of the facts of three interventions.

\section{The Case of Professors Moving from Disgruntled to Change- Making}

Background: A tiny group created an Alternate Banquet after seeing the Banquet speaker selected for the University Council for Educational Administration (UCEA). One social justice-oriented professor overheard disparaging remarks about the previous year's keynote from several established white male professors, such as "She's just telling the story of growing up poor and black in Philly. That's just a selfindulgence. Let's make sure we get somebody we know for next year's keynote and get real research." That was 1998.

Clutches of social justice-oriented professors had often gathered at conferences and shared social justice ideals and whined about how journal reviewers rejected their work. But this time they made a plan. Starting with just $6-8$ scholar-friends, they devised this Alternate Banquet. The small gathering ballooned that very evening to a group of about 30 as word spread, calling themselves Leadership for Social Justice (LSJ). Thus, the group took the bull by the horns. One activist mobilized that energy, making good use of advice from other banquet joiners and spent an entire summer securing 2 years of funding from the Ford Foundation. With the grant, she set up a strategy of RFPs (request for proposal) for mini-projects, funding them as seed grants. She also established a 12-member Board and meetings at subsequent AERA and UCEA conferences, with a succession plan for leadership. (This history is expanded on in Marshall, 2004) All members recruited others, using a brochure (see Fig. 2 below).

From this start, LSJ met semiannually at the major conferences, with food (thanks to the grant) and made the case that it should be a Special Interest Group of AERA, given its expanded membership of 250 (now 609), elected officers, a newsletter, awards, sponsored publications, and an ever-expanding base of support. People found a home, and increased outlets, for taking on the challenge to establish that social justice research had a kind of "transformational," "catalytic," and "multicultural validity" (Lather, 1991).

The field of educational administration was forever changed! Those early miniprojects were documented as chapters in Leadership for Social Justice: Making Revolutions in Education and included expanded theory, tools for social justice, such as case studies of leaders' dilemmas, tools for social justice training for school leaders (Hafner, 2010), Equity Audits (Skrla, Scheurich, Garcia, \& Nolly, 2010), and examples of leadership from African American women and leaders in Latina/oimpacted schools near the border with Mexico (Lopez, Gonzalez, \& Fierro, 2010; 
Fig. 2 Leadership for social justice brochure.

(By Marshall, Reproduced by permission)

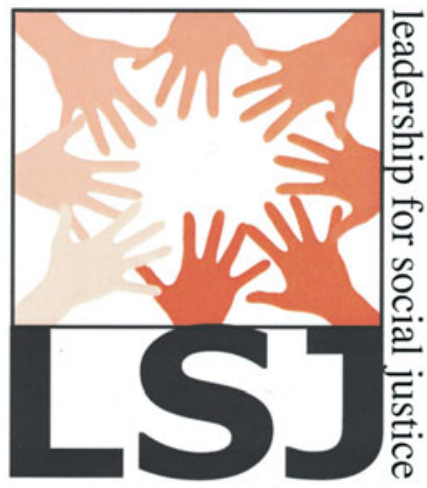

Scholars, Practitioners, Policymakers, and Students of Educational Leadership

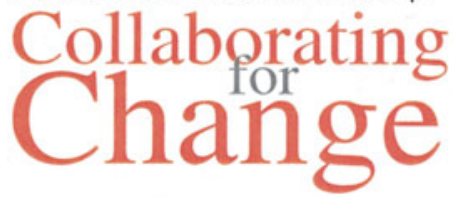

Sanders-Lawson, Smith-Campbell, \& Benham, 2010). Hundreds of publications and projects have followed, as have the proliferation of the idea in leadership preparation programs and in recruitment and promotion of professors in education.

\section{The Case of Disrupting Racism: White Teachers in White T's}

Background: The impetus came for this community activist when, in the spring of 2013, at least two of her fellow Black teachers came to her concerned about the t-shirts white teachers were wearing (Details of the event can be found in Bullock, 2015). She worked as a full-release mentor at a historically Black high school that also housed a smaller, technology-based school within the same building. This activist taught at the larger, traditional high school but mentored first-year teachers at both. The two teachers who originally approached her, Ms. Womble and Mr. Jackson (pseudonyms), taught at the smaller school.

Both teachers came to this leader concerned about the meaning of the white t-shirts the white teachers wore to school. The front contained the words "Wildershnitzel Family Reunion" with a large ensemble of all white people posed for a group picture. The picture was set in the midst of a poppy seed field from the movie The Wizard of $\mathrm{Oz}$ (LeRoy \& Fleming, 1939). A flying monkey rested at the bottom right of the scene. All of the white teachers, except for one, and a Black teacher, who was hired mid-year, wore the shirt.

Many of the Black teachers at the school expressed their confusion, frustration, and anger at what appeared to be a racially motivated act. This community activist often served as a mediator in her mentor role, and this was one of the reasons the 
Fig. 3 we are logo. (By Taylor-Bullock, Reproduced with permission)

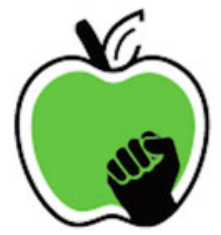

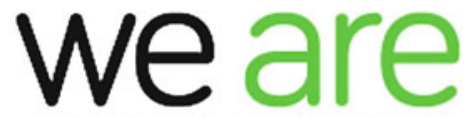

working to extend anti-racist education

teachers reached out to her. She decided to contact the principal for permission to organize a roundtable discussion to get to the bottom of why this t-shirt was created.

Almost every teacher on staff participated in the convening. In the end, it was determined that the t-shirts were made in jest, as several Black students had teased the white teachers by saying they looked alike. So the teachers decided to create shirts as if they were a part of the same family. However, none of them considered the racial implications of their actions. Both students and teachers were upset by the shirts. One Black educator shared that a student remarked, "They left off everything but the hood," alluding to clothing the Ku Klux Klan wears.

At the conclusion of this event, this community activist determined that racial equity training for teachers was needed. She cocreated a six-session institute titled, Daring Dialogue, with a colleague, one of her mentors, and her husband who was the director of social studies curriculum for the district. Little did she know, this six-session institute would be the beginning of her commitment to formally leading racial equity work in education through her future nonprofit organization we are, which stands for working to extend anti-racist education.

This activist pulled from her research on critical race theory (CRT) and critical whiteness studies (WhiteCrit) to inform the work she led through we are. Critical race scholars understand that racism is systemic and endemic in America (Bell, 1991; Crenshaw, 1988). As such, it is ever-present, and the educational field is not exempt (Ladson-Billings, 1998). This community activist used her own counternarratives (Bullock, 2018; Delgado, 1987; Solorzano and Yosso, 2002) and those of other marginalized people to propel anti-racist efforts through the grassroots efforts of we are (Fig. 3).

\section{The Case of Disrupting Heteronormativity at the Elementary Level}

After over 20 years in the classroom, this activist educator had stepped into a leadership role in a rural county. While supporting a young, talented, gay, Black teacher who took steps to disrupt heterosexism bullying in his classroom, she found herself in the midst of a contentious fight that hit national news. If the district had supported this new school leader and the teacher, this could have been a moment to teach that standing up for diversity and minorities is the right thing to do. She was frustrated when the district leaders cowered, and as a result, taught students that hate and bigotry carry more weight. 
Fig. 4 Elementary students rewriting the King and King. (Reproduced with permission from Meg Goodhand)

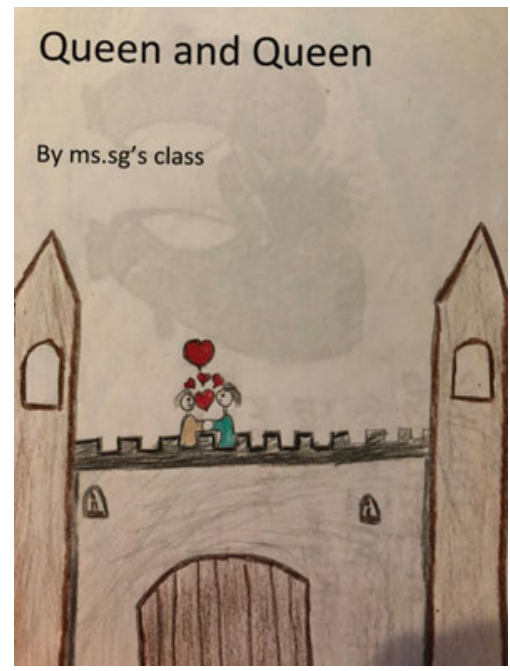

Now as principal in a new county, she relied on her research (Goodhand \& Brown, 2016) looking at teachers' ability to identify and disrupt heteronormativity in the elementary setting and her 25 years of classroom experience to support and encourage classroom teachers to initiate and pursue authentic conversations with children using age-appropriate literature. She created the first equity team at her school for the district. She now works with community organizers and the department of instruction to provide professional development on the topics of gender and race.

This educator knew primary elementary students are ready and capable of thinking through and discussing many important current social issues (e.g., gender, race). Asserted that it is never too early to start teaching tolerance of sexual orientation and sex. Research revealed that children are aware of their gender as young as 3 or 4 years of age and by the age of 9 or 10, become cognizant of their sexual orientation. She recognized that these discussions provided her students with opportunities to self-repair misconceptions and listen to each other's perspectives while gaining insight into some societal inequities (Fig. 4).

From these backgrounds, and using research on social movements and motivations for activism, we identified common themes.

\section{Themes}

With the backgrounds of the three cases, we used the reflections of the leaders in these three social justice interventions. We focused on questions about their realizations, their motivations for persevering, and their ways of managing roadblocks and stresses. In the cases' evolutions we found common themes. We now present the themes, along with illustrative narrative from the interviews for the case of 
Professors, the case of the Community Activist Disrupting Racism, and for the case of the School Leader Activist Disrupting Heteronormativity. For the most part, we use their own words.

\section{First Theme: Recognizing Exclusion}

Sad as it is - sometimes rejections is the most freeing thing in the world after you released the pain of it. Rejection opens up a world of possibilities. (Karisma Kapoor)

Each of these leaders came to recognize injustices through early life and mid-career social interactions that left them with anger and frustration and puzzlement. Their own known realities were misaligned with the powerful dominating patterns for successful social and career achievement which were, in one way or another, closed off to them. Instead of the rhetoric of meritocracy, they saw how sometimes schools were educational spaces that closed off our opportunities. In some instances they were labelled, ostracized, and isolated.

Professors: Exclusions slammed a door for this Professor leader in high school: "Injustices hit me: I was told I was a bad model for other students and not allowed to come back to school, when I got pregnant. Also I had seen there were several athletic options for boys, but only cheerleading for girls. Through college and as a public school teacher, I saw men getting promoted very quickly into school leadership and no opportunity for women in the school district. This was 1968, before Title IX. On reflection, that taught me about policies, which are mere tokens without altered values and implementation.

Except for mini bios about Harriet Tubman and Florence Nightingale, women were not part of the history in my schooling. My parents were very traditional role models so my brothers had freedoms that I did not. In retrospect, getting pregnant may have been an act of rebellion, although the shame (and motherhood) whipped me back to being mild and meek. In retrospect, I began to develop an inner strength, with an attitude of 'I'm gonna show them all' which got me through college and teaching middle school, divorce, camping across the US with my daughter to start on my Ph.D."

Disrupting Racism: Race became real to this community activist at 5-years-old when she was in kindergarten. She recalled kids sitting at round tables, and one of her white female classmates went around and invited everybody at their table to her birthday party except for her. She was the only black person at the table. She remarked, "I noticed that you invited everybody at the table to your birthday party except for me. Why did you do that?" And the student replied, "You can't come to my birthday party because my dad said Black people are not allowed in our home." This activist didn't really understand what that meant. She went home and told her mom the story.

She remembered telling her mom what happened and seeing her head turn to look at her dad. She imagined her mom was surprised to hear that story. Her mom responded by saying, "We don't invite ourselves to other people's birthday parties." That was the end of the conversation 
Disrupting Heteronormativity: When this school leader activist graduated from high school in an ultra-conservative town, she was hopeful that college life would surround her with open-minded folks. She had been brought up with parents who were liberal and believed it was everyone's duty to work on social justice issues. She was disappointed, however, when she realized that many college students had an even narrower views of the world. She identified as bisexual in college and became very isolated because she didn't fit in any community. The majority of the straight cisgender community was not welcoming in the 1980s. This activist endured slurs and lost friendships. And at this time the gay community was very protective and predominantly believed in the binary system: male/female and even gay/straight. Bisexuality was not accepted and many in the gay community believed this identity meant you were "sitting on the fence"; She was accused of being too fearful to be "out of the closet" and consequently, not welcomed in either community: gay or straight. It was disheartening and isolating.

\section{Second Theme: Recognizing Being Marginalized}

When you're marginalized, there are no "them people," if we're all on the outskirts of the same margin. (Darnell Lamont Walker)

Community Activist: At seven this activist was in Girl Scouts, and she was the only Black girl in her troop. A group of the girls were talking in a circle, and when she walked up, they stopped talking. Her best friend in the group said, "Please don't be mad at me. I'm having a birthday party later today, and my dad said that you can't come because you're Black."

This community activist thought there was something wrong with her skin color because it was keeping her out of spaces. She recalled being overcome with sadness. Her mom asked what was wrong. When the activist retold the story, this time her mom talked to her about slavery and about white people not liking Black people because of the color of their skin. She also talked about Abraham Lincoln freeing the slaves. Later, as an adult, many understand that Lincoln freeing the slaves was a little more complex than what the activist's mom shared with her 7-year-old daughter. This activist says she has been awakening since she was five and has been paying attention to race and skin color for a very long time.

School Leader Actvitist: "In the 80s, in college, queer was still considered a slur rather than a term used to express fluidity within gender and sexuality. Queer theory was just evolving within academia. It was not until the 90s that queer was embraced as a term to be more inclusive of a variety of identities. Queer theory embraces any kind of sexual activity or identity on the continuum and challenges us to rethink the traditional ways of looking at gender and sexuality." Identifying as bisexual, this college student had no community, models, or support and felt ostracized.

Being marginalized and isolated made issues of social justice personal to the three activists. 


\section{Theme: It Became Personal}

Be the change that you wish to see in the world. (Mahatma Gandhi)

Professor: "For seven years as a middle school teacher, I saw athletics for boys, girls as their cheerleaders, men promoted in school leadership, and no opportunity for women in leadership. But my gut level reaction propelled me to search for feminist literatures (there were none in my graduate school program) but also learn enough about leadership so that I could find ways to intervene effectively.

I turned anger into determination. If I had been born white male, I would not have the personal insights about things that were making me angry as a public school teacher. I got my first lesson about policy there. I was excited when Title IX was passed in Congress. But nothing changed in my district. Lesson: policy is not implemented when the values and training and leadership for implementation are not in alignment.

So I thought OK, study it more. I took a leave (and later resigned when I had had all the required admin coursework but my superintendent would not put me in line for an administrative position). While working on my doctoral degree, I convinced my professors that it was a worthwhile topic to study women's opportunities or lack thereof in school administration. I was advised to do some other topic that was more relevant, more significant, and there were no literatures really in educational leadership even though there were lots of women doctoral students. I found one or two mentors. Larry Iannacone was one, although he told me I had to teach him about women's issues, and Flora Ida Ortiz, when she was a budding doctoral candidate and then professor of educational administration, who was the only female Hispanic professor in our field in the entire United States. So she had real insights and mentored me even though she was not even a professor of my program."

Community Activist: By the time this activist left teaching in 2014 and entered a PhD program at UNC Chapel Hill, a lot had happened in the country. "George Zimmerman had been acquitted of murdering Trayvon Martin, and the Black Lives Matter movement was forming out of that tragedy. During the summer, police officer Darren Wilson killed young Michael Brown. I had a feeling I needed to be doing more. It felt like I was being called into action." She pulled upon her personal narratives and challenged herself to think about her own racialized experiences, to think about how she when she helped co-facilitate and led a six-session institute with teachers, she wondered, "What would it look like to do that on a larger scale?"

This activist started dreaming up an organization that would do anti-racism work in a systematic way. Recalling multiple uncomfortable encounters with white people, she said, "it seemed as if every day a racist incident was happening to me and it felt like God was communicating something," because the racist encounters were too frequent and other people were not having these same experiences. She drafted the goals and vision of we are in spring 2015. She started drafting what she wanted an organization to look like, what she wanted it to be called, what she wanted to do with it. 
However, self-doubt plagued her. She felt as if she didn't know enough and grew self-conscious about speaking out against white supremacy. According to her, she would tell people, "I had to put down fear and pick up faith."

School Leader Activist: This school leader's own daughters were raised by two moms. They were taught to understand that not everyone fits into the gender roles defined by our societal norms and that sexuality can be fluid. In other words, this family defined queer as "normal." But when their eldest came back from kindergarten 1 day, reporting that the kindergarten teacher said that two women can't marry each other, she knew she needed to explain the difference between a legal marriage vs. one of love. She said, "Cultural theory provides us with language to discuss how institutions and social systems replicate these norms and in turn, can have a real impact on our human agencies. It was heart wrenching watching my own children, raised to find their own path, having to navigate these waters as others told them about the shoulds of the heteronormative binary system." She had witnessed how these social constructs resulted in marginalizing all children (e.g., her own and students) that either don't conform or have family members that don't fit into these societal norms. Seeing the confusion in her 5-year-old daughter's eyes, she felt propelled and more determined. As a mother and a teacher, she felt responsible to help children develop their own agency while not feeling alienated by their peers and other teachers who socially reproduced heteronormativity.

Such realities in school and in social settings were so very powerful. Our three activists were refusing at first to recognize inequities, but then began to see now that we were quietly reproducing inequities. First they compromised to fit in and found ways to pass for gaining legitimacy within those dominant patterns.

\section{Theme: Compromising and Suppressing}

One of the greatest regrets in life is being what others would want you to be, rather than being yourself. (Shannon L. Alder)

Professor: "As a mother my one career choice was to be a teacher. But during those teacher years I recognized the need to learn about leadership and how organizations work, in order to intervene effectively. Jumping ahead, I got my doctorate in educational administration (doing a dissertation on women in administration and reading lots of literatures on women, which were never part of the grad school curriculum then, in the 1970s - not even a nod to cultural diversity). The $\mathrm{Ph}$. D. in administration was about management, literature for controlling people and keeping things orderly. Mostly bureaucratic organizational theory which is putting things in compartments and categories. Sure, organizations need some kind of structure but they don't address the complexities of what people see in schools, and they don't help you get to addressing the fact that those bureaucracies continue practices which are incredibly inequitable.

But then I got my assistant professor position. I just taught all of that old stuff. To pursue gender was a bit marginalizing. I knew that I had to research and publish what 
would get me tenure, so steering clear of marginalized feminist studies, and shifting focus to areas such as politics of education, methodology for qualitative studies. I did hear that my department chair, at my tenure hearing, said 'she does all that stuff about politics. What does that have to do with education?' Then the dean made moves, indicating he wanted to have sex with me. I squirmed my way out of that, complained to the provost but got nowhere. So I moved from Penn (but testified when other women sued).

Moving, then as associate Professor, I had tenure, and began to recognize I wasn't going to become a bag lady, with no job. I had developed quite an inner strength and shield, showing the world that I would persevere and lead, being elected to major positions at AERA. This came after publishing lots of more legitimizing work. With tenure, I still had barriers. Plus, my inattention to my children left them hanging, sometimes in trouble, and quite angry. I'm still working on healing that."

School Leader Activist: As a younger, white female teacher, this educator knew she could pass as heterosexual. Even though she was open with colleagues about her relationship, parents didn't question her. She was able to have open conversations that dealt with many social issues around gender, race, and other -isms. When she moved into her first leadership role, however, in a rural county with families that proudly displayed the Confederate flag, she became wary of being out. She noted that a conservative religious group met with students at her school. This was the first time in her adult life; at the age of 50, she chose to be closeted. "I thought I needed to shore up some legitimacy in my leadership" before she shared this personal information.

\section{Theme: Sacrifices Had to Be Made for Managing Our Lives}

There is no progress or accomplishment without sacrifice. (Idowu Koyenikan)

Professor: My sacrifices meant being poor as a single divorced woman of two adolescents while in graduate school. I sacrificed pleasure, time, fun with family, and closeness with my children, who resented my being so seemingly self-indulgent to pay my school fees. I made them the cheapest possible meals.

Community Activist: "I started my $\mathrm{PhD}$ program with a 3-year-old and a nursing 3-month-old. It was tough because not only did I leave my consistent salary with benefits but I had had another baby." There were lots of transitions happening for her family, so her husband had to be very active in his role. They had to talk about what sacrifice and compromise looked like, and it was difficult. Often this activist left her husband at home with their baby and toddler. There were definitely some role reversals. And even as socially conscious people, noted this activist, they were not immune to some of the stereotypical norms that many have been conditioned to believe. So this was another challenge. Further, the activist had 7:00 p.m. classes her first year of graduate school. She would not arrive home until close to midnight. Everyone would be asleep. "It was torture," she lamented. 
This routine created tension for her marriage and her home. They reached out to friends and family for support. "It took a village," the activist recalled, "like our daycare providers and our family" had to help carry the weight. She felt guilt for not being around for young children. "I felt like a bad mom," the activist admitted.

School Leader Activist: The school leader's daughters had their own struggles and sacrifices by having two moms. Her second daughter had always been open with her peers about having two moms, but in middle school, her friends refused to spend the night in a house with lesbians. Her third daughter just introduced her second mom as her aunt. The daughters had many internal struggles with how to bridge their lives at school and their peer relationships with their own family life that did not consist of the traditional, acceptable mom and dad.

These moments of sacrifices and tensions in their lives had affected them so profoundly that they felt compelled to find ways to speak out and address these microaggressions.

\section{Theme: Finding Voice}

Each activist found outlets, ways to express their voice. Sometimes it seemed like they were seeing a need that others sort of saw but did nothing with. Sometimes the issues were so "out there" that they were "Catching the wave." Recognition became, increasingly, a propelling force

A voice is a human gift; it should be cherished and used. Powerlessness and silence go together. (Margaret Atwood)

Professor: Motivation came from so many conversations, with an array of other scholars in educational administration who were frustrated with the narrow parameters on scholarship in their field and who tried to push into areas that were not just about what's an effective school and what is an effective manager. "At conferences like the American Educational Research Association (AERA) and University Council for Educational Administration (UCEA) - that was the main way of conversing back then - we didn't have email, texting etc. We egged each other on."

Community Activist: This activist cocreated a document overview for the six sessions of Daring Dialogue, equipped with rationale and research. She pulled together a team to plan and facilitate the work together: her husband, another colleague who taught English, and her former college professor. She pitched the idea of the sessions to her principal and asked if he would pay teachers to stay after school for the six sessions. He agreed to allocate school funds to provide food, stipends to the attendees, and stipends to the planning team. "We hoped to engage teachers in conversations that would enhance their understanding of race and ethnicity in education, leading to improved teacher to teacher and student to teacher relationships." Ultimately, the team believed the institute experience would help improve educational outcomes for students. A local chapter of the Young Women's 
Christian Association (YWCA) lent the team a curriculum they created to guide the planning.

In the spring of 2014 the activist and her co-facilitators implemented the sessions. In hindsight, she realized that "We were doing this planning right as the Black Lives Matter Movement was taking the U.S. by storm." That fall, she entered her PhD. program and took the momentum from Daring Dialogue with her.

School Leader Activist: A talented teacher in third grade was dealing with bullying in his class around the topic of gender. He needed support when he decided to take action with the book, King and King (de Haan, 2003). In this book, a queen orders her son to marry so he can rule the kingdom. After many princesses are paraded in front of him, he does fall in love... with a male page. They get married and live happily ever after. This book is written for early elementary ends with a simple drawing of the two kings kissing.

The teacher knew the activist school leader had a copy of King and King on her special shelf of books with topics of social justice. The school leader was hesitant as she was new to this school community and had decided to be closeted for the first time in her adult life, in this rural county with conservative families that were blatantly racist and likely homophobic. But it was clear in this teacher's determination that action needed to happen to help his students. The educators recalled hearing that after the class read King and King, one of the boys who had been teased and bullied for his nonconforming gender mannerisms went straight to his reading teacher and stated, "I can walk how I want now." Although that's not the theme of the book, this boy was able to deduce this idea of acceptance of nonconforming gender roles through this story.

Thus, summarizing the theme of finding voice, President Obama's quote is useful: "One voice can change a room, and if one voice can change a room, then it can change a city, and if it can change a city, it can change a state, and if it can change a state, it can change a nation, and if it can change a nation, it can change the world. Your voice can change the world."

\section{Theme: Organizing with Others}

Solidarity is not an act of charity, but mutual aid between forces fighting for the same objective. (Samora Machel)

The activists were translating their personal motivations into actions of solidarity and partnership with others and becoming a voice with others.

Professor: "With wine flowing, as others trickled in to find us, having given up on the Conference Banquet, we whined some more - about how journal reviewers sent our work back with comments like, 'this is lovely but subjective,' or 'personal narratives aren't real data.' Whining got more constructive as we decided to be a group. Late in the evening, someone said, 'so we're all feeling determined and then we go home and nothing changes.' After that small group 
met at the restaurant, we used our anger to build momentum. That was the birth of LSJ."

Community Activist: "we are provides anti-racism training for children, parents, and educators with the ultimate goal of dismantling systemic racism in education and beyond. The organization uses a three-pronged approach to achieve its goals by providing summer camps for children in first through fifth grade, professional development for educators, and workshops for parents. we are triangulates its involvement in hopes of changing culture and changing systems in ways that have a lasting impact. The work takes into account both micro and macro forms of racism, the individual and systemic levels."

This activist's husband was supportive of we are and helped bring all of her ideas together in the early planning stages. As she reached out to get help from friends to plan and develop we are, the activist had acquired a fancy logo and pamphlet that provided a detailed overview. She recruited her husband, a former colleague who had helped plan Daring Dialogue, the fourth co-planner of Daring Dialogue, and then she recruited some people in her $\mathrm{PhD}$ program, based on the comments they would make in class. They started having planning meetings and thought through what the first summer camp would look like, which they piloted in 2016.

School Leader Activist: When a parent from another room made a formal complaint regarding the reading of King and King, the new school leader tried to deflect the blame from this new teacher by telling her principal that she had given him the book. When they were called into the principal's office, the teacher was going to resign. But the school leader encouraged him to stay assuring him that she would be by his side every step of the way. They repeatedly requested meetings with district leaders but it became clear that no one was willing to support them. In the meantime, HR put a lot of pressure on the school leader, wanting a formal statement declaring that there was no bullying going on in that teacher's room (which had been the "safe" justification for the book selection). But they stood their ground and refused to succumb to their intimidation tactics. The backlash was visceral. This story manifested into headlines on the national news. The activist school leader recalled, "At one of the open public meetings, it was declared that we had conspired to present a gay agenda and had blood on our hands. Trying to be brave for this teacher, I was scared but found courage when local groups and individuals showed up at the public forums to support me and the teacher."

Organizing for collective action is vital for activists to gain power necessary to overcome the oppression and injustices of our society. These leaders found within their communities agencies and individuals ready to support them as they confronted these inequities.

\section{Theme: Overcoming Barriers}

The real test is not whether you avoid this failure, because you won't. It's whether you let it harden or shame you into inaction, or whether you learn from it; whether you choose to persevere. (Barack Obama) 
In those collaborations with others, these activists found ways to take an intervention in new directions. Still, they encountered barriers along the way.

Professor: "Recountings above describe my struggle with hostile environments, getting tenure, inner struggles to avoid being labeled as a discomforting feminist with a chip on her shoulder, maintaining that shield, needing to establish myself in other areas like qualitative methodology and politics."

Community Activist: Some of the barriers early on, as this activist noted earlier, were related to her language and what she was saying - either on social media or in conversations with others. "I was very explicitly talking about white supremacy and wanting to do something to challenge it. That language put some people off. I had friendships that were no longer the same. I made a conscious decision to distance myself from them because if they would have remained close, I would not have been able to grow the way I needed."

The activist shared that her friends continuously tried to tone her down, but in her words, she's "not even that radical." For that time period, however, talking about white supremacy was not as common as it has now become, since Charlottesville and the 2016 election. Through Facebook, she had amassed a significant following, but many of the people closest to her were not feeling what she was saying. Speaking about white supremacy, calling it out, being visible, and being very intentional about language was off-putting to some Black folks.

As a reflective person, she listened to feedback and questioned whether or not she was making the right decision to overtly challenge racism. At every turn where she would second guess herself or question her own sanity, she said, "God was giving me signs saying, 'No, speak! You are doing what I called you to do. I have given you these talents and skills' to do this work." All of these signs were affirming her path. She recalled, "I trust in my faith that things will work out the way they are supposed to because I'm being obedient to the spirit."

School Leader Activist: Certainly, as a lesbian and an educator, this school leader has encountered dismay, fear, and even disgust from colleagues. Additionally, taking on the topic of gender and sexuality at the elementary level has been controversial. Meyer (2010) shared embracing diversity in regard to sexual orientation is one of the most challenging areas in standards implementation. During the King and King incident, another teacher made it clear in the meetings that the theme of the book was very disturbing to her as a devout Christian. Previously, she had a close relationship with this talented teacher, but when the book controversy arose that teacher took action. She leaked information to the families regarding the school-based meetings to discuss the book and she expressed her disgust openly. This teacher eventually found a job at a Christian school. There were several other teachers who stopped communicating with the school leader. The school leader activist recalled how hard and lonely it was for her in those last few weeks before she and the King and King teacher resigned. But she knew she couldn't continue to be a leader in a community where she would have to feel ashamed or afraid to support all students.

In these scenarios, there was resistant to social change. For most it was uncomfortable and involved upending long-held traditions or looking at injustice from a 
new angle. People have a natural tendency to choose comfort and stick with what they know. These activists persevered through these barriers.

\section{Theme: Intervene Early}

It is time for parents to teach young people early on that in diversity there is beauty and there is strength. (Maya Angelou)

Professor: New scholars in the field found a home in LSJ while looking for collaboration with others who, while less vested in the scholarly career, were also less entrenched in the fear of working the field differently. Many saw LSJ as a place for combining their voices and realities with their scholarship and the positions and publications that would allow them success as they carved their careers and publications through this new scholarship. "Newbies joined in!"

Community Activist: Her first area of interest for we are was working with children. Most anti-racism efforts are geared toward teenagers or adults. She specifically chose to target elementary-aged children because anti-racism efforts must begin earlier in life. The loss of Trayvon Martin taught her that white adults often encounter Black people through tropes, either that of an athlete, an entertainer, a criminal, or a thug. There is not a nuanced way of experiencing Black people because of how they have been presented through these narrow, stereotypical lenses. And so in thinking about, for instance, Daring Dialogue, for some of those teachers, this activist felt hopelessness because it seemed too late for them to start developing an anti-racist identity Many of them had been conditioned to hold biased beliefs for so long, and it would be really hard to shift those beliefs and behaviors with antiracism training. The activist believed that starting at an earlier age was more promising. This is one of the main reasons why we are's anti-racism summer camps focus on children in rising first through fifth grade.

School Leader Activist: Elementary students can easily learn to accept the continuum of diversity within these topics of gender, interests, and issues surrounding the LGBTQ community. "My experience with King and King reaffirmed my commitment to continue this work at the elementary level." She knew that issues of social justice needed to be addressed with children at a young age before misinformation, confusion, and stereotypes lead to intolerance and prejudices. With tolerance and acceptance, educators can facilitate an environment that is free of persecution, homophobia, and oppression. If educators create this type of climate, children will be better equipped to live in a multicultural society.

Anti-bias, culturally sensitive teaching and learning needs to be prioritized in early childhood and first career environments. These activists call attention to the ways in which people are different and the ways in which people are the same, honoring individual and group identity. They intentionally introduce issues of fairness and unfairness, and coach children to think critically and to take action. And for adults, they knew spaces were needed to envelop layers of support for the social justice courage acts. 


\section{Theme: Legitimacy}

How to build a fire: stay true to your perspective! Then burn. (Ralph L. Harmon)

The leaders knew to position their actions strategically. Perhaps this only happened because they already knew, from that early acculturation, that they had to establish legitimacy.

Professor: "I had long before learned I must achieve a lot to protect my flanks, to make my classes superb, to invite complaints, I had to be pleasant, had to be constantly guarded but ready to reclaim my feminist activist and scholar self. I also knew that gender work, alone, could not get wide attention and followers."

But lots of scholars wanted an array of "isms" addressed, knowing that activists and agitators alone would not make things happen without swaying the field and practice of leadership. "After the 'alternative banquet' and me devoting an entire summer to set it up, LSJ was a structure with Ford Foundation funding for mini projects, with a board to review them. This built a strategy to overcome AERA roadblocks to a special interest group. Leadership, combining with that array of folks wanting to address the 'isms' was key."

Community Activist: "I didn't go into the $\mathrm{PhD}$ program thinking that I needed a degree to validate my work. I initially wanted to become an elementary school principal and thought having research skills would make me a better leader. However, as a Black woman doing race work, having that extra validation goes a long way. It is easier for people to be dismissive of what I am saying, without the degree." Of course this does not exempt her from facing stereotypes of playing the race card or being labeled an angry Black woman. But in academic spaces, having a doctorate degree lends legitimacy to her work. When people see that a person with a doctorate is presenting an anti-racism workshop, it matters.

As these activists worked to confront these negative social norms, they recognized they needed a sense of trust and legitimacy.

\section{Theme: Tangible Symbols}

\section{Symbols can be so beautiful, sometimes. (Kurt Vonnegut)}

In each instance, the activist leaders were creating tangible identifiers of the intervention - in symbols, and tangibles such as a logo/name, materials, and pamphlets. This provided powerful symbolic association connected to their work.

Professor: "Certainly that brochure, a newsletter, and a burgeoning membership were symbols of success. The brochure was placed all over the conferences. An increasing number of books were tangible signifiers. Articles by many scholars, signaled to all that social justice, was being embedded by a succession of new leaders in LSJ."

Community Activist: "I am a pencil and paper kind of girl." She started writing out ideas for what the organization would be called. She wanted to ensure that in the 
title, people understood who they were. She and her husband were playing around with ideas to think through different names. Somehow they came up with working to extend anti-racist education.

After they had the title, the activist started thinking about the logo and getting a graphic designer. She gave the designer color suggestions and the request to include an apple and a fist. The designer adjusted lettering that helped soften the title, to make it palatable so that parents would feel comfortable allowing their children to participate.

"It was important that anti-racist was in the title because it evokes different feelings versus terms such as inclusion. We wanted people to know that we were not just doing diversity work. She noted, "I never want a parent or a teacher to show up to a training thinking they were tricked to be there." Some people advised her to take the black fist off or take anti-racism out of the title. "I imagine," the activist said, "our title and logo tell some people to walk away, and for others, it tells them to come."

School Leader Activist: To support a paradigm shift at the elementary school this school leader regularly shares information and research with faculty and stakeholders (e.g., parents, district leaders). Yearly she asks the staff to read, Good morning boys and girls (Bigler, 2005) to support their understanding of gender fluidity and sexuality. Bigler states how we reproduce culturally constructed norms through our language and actions such as setting competition or lining up children by perceived gender. The article, asserts that we should avoid making these statements along racial lines (e.g., Latinas line up first). This education leader believes that as we work to have dialogue among staff about issues of gender, teachers will support this shift in their classroom environments and proactively confront the social norms reproduced in school. Now, her leadership team recently rewrote their vision statement for the school, "A neighborhood school working toward an equitable world to reflect this shift in our culture. Each year, I share a letter with our families that states that teachers will explicitly talk about social issues within our school, and will integrate curriculum with literature such as I am Jazz (Herthel, Jennings, \& McNicholas, 2014)."

Symbols are an integral part of our lives. Constructing symbols carefully can help to define perception; they shape the way we think and assists these activists with legitimizing their vision and work to change societal norms.

\section{Theme: Funding and Structure}

Creation has to go hand and hand with social justice. (Shekar Prabhakar)

As they developed systematic ways to address injustices, the interventions had clear indications that they had become legitimate. Thus, each leader molded her realizations and determination to intervene to fit into existing structures, aligned with regularized and legitimized activities. They found ways to raise seed money through grants to support this work. In doing so, they were finding ways to capitalize on it for themselves - gaining a sense of self-truth, integrating with their other work. 
Professor: "I remember how AERA put up barriers, saying social justice didn't have enough theoretical grounding or research base. But structure and legitimacy came with designating responsibilities (e.g., for officers, personnel recruitment, by-laws for LSJ). In doing so, we were finding a path to success... with by-laws and succession of new leadership. That theoretical base and research flowed, set up in the thinking that went into the Ford grant."

Community Activist: "I engaged in fundraising through general donations and crowdsourcing with Go Fund Me. The plan now is to apply for other grants. The organization needs funding to build infrastructure and grants from foundations are better able to support this need." we are received a $\$ 125,000$ grant from the William R. Kenan Charitable Trust. This 2-year grant allows the activist to work with three local elementary schools, helping to address systemic racism in their school community. There is potential to receive additional support for future work beyond doing this project with these three elementary schools.

School Leader Activist: Within her graduate studies, this educator researched disrupting heteronormativity at the elementary level; She worked with a group of volunteer teachers to explore their beliefs and attitudes regarding children who display atypical gender expression and children, families or colleagues who identify as LGBTQ. These teachers intermingled stories of children in their classrooms with their own upbringing at home and at school as they tried to construct together their understanding of heteronormativity and its impact on the climate at the elementary school level. By addressing their own misperceptions or lack of awareness, these teachers coconstructed new understandings of how norms and values play a role in their expectations and choices within their classrooms and schools. "The experience was transformative. These teachers were willing to use their voices and understandings to engage in this work and to confront heteronormativity within other school settings and levels. I continue this work as a school leader, with professional development, and I present at our annual SafeSchool conference."

The activists were aware that for these changes to be sustainable there needed to be a structure along with funding sources. With this initial work to provide a framework, these activists create a potential for more grants for nonprofit advocacy, community organizing, and civic engagement.

\section{Theme: Support Networks}

Networks were sought from among allies and among those preexisting structures. Cultivating compatriots partners and personal supports to help manage the new, extra demands

We don't heal in isolation, but in community. (S. Kelley Harrel)

Professor: "For me personally, I had established legitimacy, written about combining feminism with power and politics (Marshall, 1997), and moved positions and 
states when I faced barriers, to find a more supportive university and a more stable life. Even that hard protective shield can soften!"

Community Activist: Support was not lacking for this activist. She and her husband connected with the leadership of the Samuel DuBois Cook Center for Social Equity at Duke University. "They agreed to financially support the first event the activist we would lead through we are, the Let's Talk Racism Conference."

After they established that partnership, the activist and her husband applied for a grant through CUBE, a social entrepreneurial incubator space. They received $\$ 5,000$ in seed money, mentorship, and access to different programs which helped the activist think through growing a social venture. Last, the activist also built a partnership with a local Ben \& Jerry's franchise, which now cosponsors all of we are's events.

School Leader Activist: Throughout the protests in the rural county, community support and allies were present. "I was president of SafeSchools NC, a statewide organization dedicated to teaching others about LGBTQ+ issues and inclusive learning environments. This group of volunteers supported the King and King teacher and me through letter writing and attending the public meetings." Recently the National Education Association (NEA) joined with the Human Rights Campaign to support school-wide readings across the country of I am Jazz, a book about a transgender girl. Having NEA endorse this book provided the legitimation of using this literature at the elementary level.

These activists sought out and found the support needed for this vision. "If you want to go fast, go alone, but if you want to go far, go together." This African proverb rings true in this work for social justice. The social change movement relies on networking our individual efforts with one another to create unified action with a shared vision.

\section{Theme: Success}

I alone cannot change the world, but I can cast a stone across the waters to create many ripples. (Mother Teresa)

What evidence exists that these leaders' interventions there have had successes and growth?

Professor: "Success means seeing so many major books (for starters, see the authors in Tillman and Scheurich (2013); Brooks and Normore (2018), and this Handbook), and articles with titles designating social justice. And social justice in so many graduate program curricula. For me personally, getting major awards for lifetime achievements but seeing that flourishing membership of LSJ, and being called the grandmother of LSJ. I see former students (like my co-authors) working towards social justice, and guiding current students focusing on women superintendents' narratives, on social justice issues inherent in dress code policies, and more." 
Community Activist: "When we are co-hosted the Let's Talk Racism Conference with North Carolina Central University's (NCCU) School of Education (SOE) in 2016, we had about 150 people to register, and then 250 the second year. That year Dr. Bettina Love of University of Georgia served as the keynote. She was phenomenal and talked about the push out of girls of color. At the third annual conference, about 300 people registered." Partnerships along with the growth in conference attendance made the activist feel that they were being successful in educating people about systemic racism.

We saw growing numbers at the conference, the summer camps were scaled up, as well. The activist and her organization piloted the program with kindergarten through second grade participants. Eventually they will add a pre-K/kindergarten curriculum, that is, play based, to share with pre-K centers. The next summer, we are hosted a first through second grade week of camp and then added a third through fifth grade week. The younger camp grew from 15 to 23 participants, and the third through fifth grade camp started with 33 . The interest was so overwhelming that they had a waitlist for both.

Over 80 children participated between the two camps by the third summer. Families paid for their children to participate; however, the organization offers free and partial scholarships to families who demonstrate a need. we are fundraises to get money to cover the scholarships.

School Leader Activist: This school leader has been affirmed to see how her daughters have grown in accepting being part of a queer family. "My third daughter now brags that she has two moms, while my first daughter, whose teacher said women can't marry, is happily engaged to a woman."

As principal, she has adopted the school-wide reading of I am Jazz. The first year she had some pushback but by the second year, she only heard words of appreciation for including this book. The deliberate steps she took to work on social justice issues have proven to show an impact at this school. Teachers are sharing literature with characters that are gay or have non-conforming gender traits. In one elementary classroom the students decided to make a petition to encourage others to stop saying that's so gay. These conversations are affirming and help create a more inclusive school culture.

This school leaders says, "All school leaders must challenge the silence around taboo topics of gender and sexuality. One of the 4th grade teachers at my school displayed this quote by Harvey Milk, a LGBTQ activist, 'Hope is never silent.' Many colleagues approached the teacher to declare, 'You can't do that' and knowing her school leader had her back, she retorted, 'Yes, I can,' and later a parent thanked this teacher for the quote. It is essential for all children and families to be welcomed and affirmed within the school. You have to be at a place in your heart to take risks, to speak up and challenge the norms reproduced in schools. Harvey Milk's words, 'Hope is never silent,' gives her courage and reminds this leader that we must keep speaking up for all."

Each of these activists had clearly defined the change needed. Their messages were consistent and with each barrier they overcame, their vision became clearer. Through their sacrifices, organizing, and building a support network, they each experienced success. 


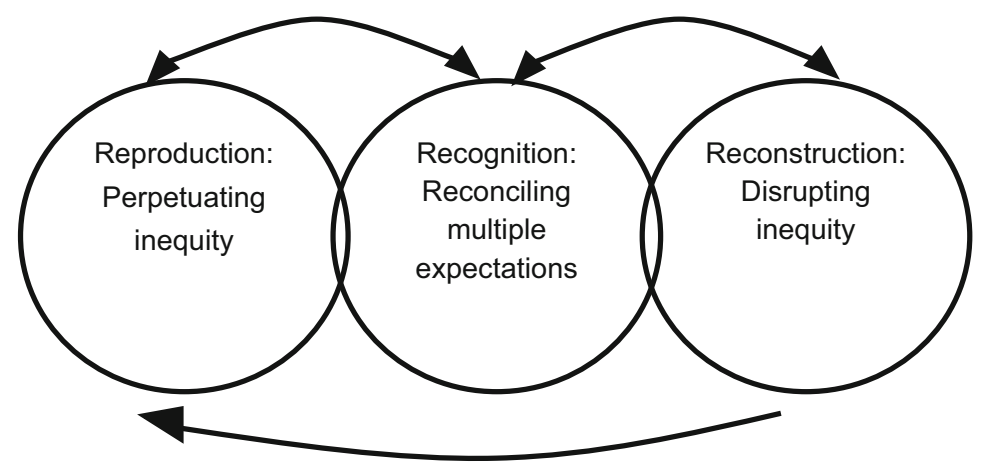

Fig. 5 The Wider Societal Challenge (Rorrer, 2002). (Reproduced by permission, UCEA Review)

\section{Conclusion}

What does this mean, as people progress from realizing that inequities are being perpetuated toward actually finding ways to intervene, toward actually making a difference? In these cases, Rorrer's model serves to organize our common evolutions from perpetuating inequality, then disrupting, while recognizing ways to make the disruption fit with others' expectations (Fig. 5).

As depicted, this model calls attention to some realities (in ways that Theoharis's model did not include). It portrays, as the cases above do, the reality for educators who simply fit within the ways of getting by in education careers are, in a way, reproducing inequity. It portrays a reality, that the educators who can no longer stomach this, are propelled to action; then they are buffeted with the career and family expectations and barriers and resistance. Another reality portrayed a reconstruction, in which the leadership for intervention does, eventually, disrupt inequities, in ways that build a base for others to work from.

Questions remain. Can grassroots movements suffice? Can they gain enough momentum and credibility to be replicated and institutionalized across larger social and political systems, thus altering assumptions about what is right and good? Is it enough to create safe spaces for particular strategies? How much and how long can individuals endure the losses, the labels and innuendo and isolation that may be consequences of speaking and acting out? Still, our three cases are embedded with inspiration and lessons that are transferable to other times and places and social movements, turning a ripple into a wave.

\section{References}

Bell, D. (1991). Racial realism. Connecticut Law Review, 24, 363.

Bigler, R. (2005, Fall). Good morning boys and girls. Retrieved September 22, 2018, from https:// www.tolerance.org/magazine/fall-2005/good-morning-boys-and-girls 
Brooks, J., \& Normore, A. (Eds.). (2018). Leading against the grain: For creating just and equitable schooling. New York, NY: Teachers College Press.

Bullock, R. T. (2015). White teachers, white T's, and white privilege [blog post]. Retrieved November 4, 2018, from https://rebirthofan8ion.blogspot.com/search?updated-max $=2015-06$ 05T14:18:00-07:00\&max-results $=7 \&$ start $=21 \&$ by-date $=$ false

Bullock, R. T. (2018). Raising conscious kids: A community-based approach. In K. Daniels \& K. Billingsley (Eds.), Creating caring \& supportive educational environments. Hershey, PA: IGI Global.

Crenshaw, K. W. (1988). Race, reform, and retrenchment: Transformation and legitimation in antidiscrimination law. Harvard Law Review, 101, 1331-1387.

de Haan, L. (2003). King and king. Berkeley, CA: Tricycle Press.

Delgado, R. (1987). The ethereal scholar: Does critical legal studies have what minorities want? Harvard CR-CL LR, 22, 301.

Goodhand, M., \& Brown, K. M. (2016). Heteronormativity in elementary schools: The hidden and evaded curricula of gender diversity. International Journal of School and Cognitive Psychology, 3, 188. https://doi.org/10.4172/2469-9837.1000188

Hafner, M. M. (2010). Teaching strategies for developing leaders for social justice. In C. Marshall \& M. Oliva (Eds.), Leadership for social justice: Making revolutions in education (pp. 194-214). Boston, MA: Allyn \& Bacon.

Herthel, J., Jennings, J., \& McNicholas, S. (2014). I am Jazz! New York, NY: Dial Books for Young Readers, an Imprint of Penguin Group (USA) LLC.

Ladson-Billings, G. (1998). Just what is critical race theory and what's it doing in a nice field like education? International Journal of Qualitative Studies in Education, 11(1), 7-24.

Lather, P. (1991). Getting smart: Feminist research and pedagogy with/in the postmodern. London, England: Routledge \& Kegan Paul.

LeRoy, M. (Producer), \& Fleming, V. (Director). (1939). The wizard of $\mathrm{Oz}$ [Motion Picture]. United States: Metro-Goldwyn-Mayer

Lopez, G. R., Gonzaliz, F. L., \& Fierro, E. (2010). Educational leadership along the U.S.-Mexico border: Crossing borders/embracing hybridity/building bridges. In C. Marshall \& M. Oliva (Eds.), Leadership for social justice: Making revolutions in education (pp. 100-116). Boston, MA: Allyn \& Bacon.

Marshall, C. (1997). Feminist critical policy analysis. London, England: Falmer Press.

Marshall, C. (2004). Social Justice Challenges to Educational Administration: Introduction to a Special Issue. Educational Administration Quarterly, 40(1), 5-15.

Marshall, C., \& Oliva, M. (2006). Leadership for social justice. Boston, MA: Allyn \& Bacon.

Meyer, E. (2010). Gender sexual diversity in schools. New York, NY: Springer Science \& Business Media.

Rorrer, A. (2002). Educational leadership and the institutional capacity for equity. The UCEA Review, 43(3), 1-5.

SAFESCHOOLSNC. (n.d.). Retrieved September 22, 2018, from https://www.safeschoolsnc.org/

Sanders-Lawson, E. R., Smith-Campbell, S., \& Benham, M. K. P. (2010). Wholistic visioning for social justice: Black women theorizing practice. In C. Marshall \& M. Oliva (Eds.), Leadership for social justice: Making revolutions in education (pp. 74-94). Boston, MA: Allyn \& Bacon.

Skrla, L., Scheurich, J. J., Garcia, J., \& Nolly, G. (2010). Equity audits: A practical leadership tool for developing equitable and excellent schools. In C. Marshall \& M. Oliva (Eds.), Leadership for social justice: Making revolutions in education (pp. 259-280). Boston, MA: Allyn \& Bacon.

Solorzano, D. G., \& Yosso, T. J. (2002). Critical race methodology: Counter-storytelling as an analytical framework for education research. Qualitative Inquiry, 8(1), 23-44.

Spring, J. (2013, March). Teaching tolerance. Best practices: Creating an LGBT-inclusive school climate. Southern Poverty Law Center. Retrieved from http://www.tolerance.org

Spring, J. (2018). American education (18th ed.). New York, NY: Routledge Falmer.

Theoharis, G. (2004). At no small cost: Social justice leaders and their response to resistance. Unpublished dissertation, University of Wisconsin, Madison.

Tillman, L. C., \& Scheurich, J. (2013). Handbook of research on educational leadership for equity and diversity. Abingdon, UK: Routledge. 